\section{Australian Journal of \\ Crop Science}

AJCS 15(04):602-609 (2021)

doi: 10.21475/ajcs.21.15.04.p3071

\title{
Soil quality bioindicators in initial eucalyptus growth under organomineral fertilization based on sugarcane filter cake
}

\author{
Julio Cesar Delvaux ${ }^{1 *}$, Reginaldo de Carmargo², Regina Maria Quintão Lana ${ }^{2}$, Miguel Henrique \\ Rosa Franco ${ }^{2}$, Mayara Cristiana Stanger ${ }^{2}$, Rafael Arcanjo Gonçalves ${ }^{1}$, Ernane Miranda Lemes ${ }^{2}$, \\ Paulo Sérgio Balbino Miguel ${ }^{3}$
}

\author{
${ }^{1}$ Instituto Federal de Educação, Ciência e Tecnologia do Triângulo Mineiro, Campus Ituiutaba, Ituiutaba, Minas Gerais, \\ Brazil \\ ${ }^{2}$ Instituto de Ciências Agrárias, Universidade Federal de Uberlândia, Uberlândia, Minas Gerais, Brazil \\ ${ }^{3}$ Instituto Federal de Educação, Ciência e Tecnologia de Roraima, Campus Amajari, Amajari, Roraima, Brazil
}

\begin{abstract}
Pelletized organomineral fertilizers (OMFs) are a promising, sustainable alternative for eucalyptus fertilization, the most widely cultivated hardwood tree globally. However, little is known about the effects of OMFs on initial plant development and soil quality. We evaluated the effects of different doses of a pelletized OMF derived from sugarcane filter cake $(0 \%, 50 \%, 100 \%, 150 \%$, and $200 \%$ relative to the recommended phosphorus dose for cultivation) and a mineral treatment (mineral fertilizer at the recommended dose for eucalyptus), as well as the effects of time $(30,60,90$, and 120 days after transplanting), on the morphophysiological responses of eucalyptus plants (diameter at neck height, plant height, and chlorophyll $a$ and $b$ content) and soil pH, microbial biomass (MBC), and microbial activity (soil basal respiration [SBR]). Increases in fertilizer dose led to increased chlorophyll $a$ values, but values decreased under the highest doses (150\% and $200 \%)$. OMF addition led to an initial increase in soil $\mathrm{pH}$, followed by a reduction. The highest values of plant height, stem diameter, and fresh and dry masses of leaves, stems, and roots were observed when the OMF dose of $50 \%$ was administered. MBC values were inversely proportional to the OMF dose, and the SBR and metabolic quotient $\left(\mathrm{qCO}_{2}\right)$ values observed under the $50 \%$ and $100 \%$ treatments were equal to or better than those observed under the mineral fertilizer treatment. Pelletized OMFs derived from filter cake could potentially replace mineral fertilization in the early development of Eucalyptus urophylla $\times$ Eucalyptus grandis without damaging soil quality.
\end{abstract}

Keywords: E. urophylla $\times$ E. grandis, microbial biomass carbon, microbial biomass activity, indicators of soil quality.

Abbreviations: OMFs_organomineral fertilizers; DAT_days after transplanting; MBC_microbial biomass carbon; SBR_soil basal respiration; $\mathrm{qCO}_{2}$ metabolic quotient; WRC_water retention capacity; FML_fresh mass of the leaves; FMS_fresh mass of the stem and branches; FMR_ fresh mass of the roots; $\mathrm{DML}_{-}$dry mass of the leaves; DMS_ dry mass of the stem; DMR_dry mass of the roots; $\mathrm{Chl} a_{-}$chlorophyll $a$ content; $\mathrm{Chl} b_{-}$chlorophyll $b$ content.

\section{Introduction}

In Brazil, fertilizer imports account for an average of $79 \%$ of consumption, and it is estimated that the reuse of agroindustrial waste has the potential to generate 5.3 million tons of nitrogen, phosphorus and potassium (NPK) (Cruz et al., 2017). Sugarcane filter cake may be a promising method of reusing agroindustrial waste due to the large amounts of sugarcane produced in Brazil, which could potentially be used to produce 254.2 million tons of filter cake annually (CONAB, 2018).

However, the direct use of filter cake is not viable in areas far from manufacturing plants, with losses of the nutrients contained in these residues occurring frequently (Oliverio et al., 2011). In this context, the composting and pelletizing processes maintain the uniformity of the physical characteristics of the product, and enable the use of mineral fertilizers as pellets (Romano et al., 2014).

In Brazil, the forestry sector demands 962 thousand tons of fertilizers annually. Cultivation of the Eucalyptus genus represents a large proportion of this, with 5.7 million hectares planted in 2017 (IBÁ, 2018), and with the interspecific hybrid $E$. urophylla $\times$ E. grandis being the most cultivated variety by area (Fowler, 2014). Obtaining high yields for this genus requires a large nutrient supply, especially in the period between transplanting and the touching of the tree tops (Barros \& Camerford, 2002). However, even if large nutrient inputs result in production gains, they may lead to reduced soil quality (Zhao et al., 2013), which can be measured using indicators that are capable of reflecting the environmental condition of the ecosystem (Araújo and Monteiro, 2007). Two such indicators are microbial biomass and microbial activity, which have been utilized in approximately $25 \%$ of all previous forest soil studies (Bünemann et al., 2018).

The production of OMFs based on filter cake has emerged as an innovative solution that combines the increased yields provided by mineral fertilization with the economic and environmental viability of waste reuse (Cruz et al., 2017). The viability of this technique has already been confirmed in 
sugarcane (Ramos et al., 2015) and sorghum (Oliveira et al., 2017). However, there have been few reports examining the effects of OMFs on the initial development of eucalyptus seedlings and on soil quality. Thus, the objectives of the present work were to monitor the morphophysiological responses of eucalyptus plants, changes in soil microbial biomass, and changes in soil microbial activity in response to different doses of an OMF.

\section{Results}

\section{Initial development and physiological performance}

During initial plant development, both organomineral fertilizer dose and number of DAT significantly affected mean height $(\mathrm{H})$, diameter at neck height (DN), chlorophyll $a$ content $(\mathrm{Chl} a)$, and chlorophyll $b$ content ( $\mathrm{Chl} b)$ (Supplementary Table 1).

Lower increases in mean height $(\mathrm{cm})$ were observed at 30 and 60 DAT at OMF doses of $100 \%, 150 \%$, and $200 \%$ compared to the $50 \%$ dose and to the control (Table 1 ). [insert Table 1 here]

At 30 DAT (Supplementary Figure 2) and 60 DAT, OMF doses of $100 \%, 150 \%$, and $200 \%$ lead to lower plant height compared to the control and to the mineral fertilizer treatment ( $100 \%$ of the recommended dose). However, at 90 DAT and 120 DAT (Supplementary Figure 3), only the dose of $200 \%$ lead to lower plant height compared to the mineral fertilizer treatment (Table 1). A similar pattern was observed for the diameter at neck height (Table 1).

Increases in Chlorophyll $a$ contents were verified during plant development, with maximum levels being achieved at 89 and 74 DAT for the OMF doses of $50 \%$ and $200 \%$, respectively, with no models fitted for $0 \%, 100 \%$, and $150 \%$ (Table 2).

Increases in fertilizer dose led to increases in chlorophyll $a$ values, but values were reduced under the highest doses (150\% and $200 \%$ ). The maximum chlorophyll $a$ values at 30 , 90 , and 120 DAT were observed for the doses of $159 \%$, $153 \%$, and $118 \%$, respectively, with no model fitted for 60 DAT (Table 2).

Similarly to chlorophyll $a$ content, there was an increase in chlorophyll $b$ content as OMF dose increased, while chlorophyll $b$ content decrease at the highest OMF doses (Table 2).

At 30 DAT, there was an increase in $\mathrm{C}-\mathrm{CO}_{2}$ emissions caused by increased doses of organomineral fertilizer, with subsequent decreases at higher doses. The greatest $\mathrm{C}-\mathrm{CO}_{2}$ emissions were observed under the $142.7 \%$ dose and, at 120 DAT, there was a linear increase in RB values as a result of increased dose (Figure 4A).

[insert Figure 4 here]

Apart from the treatment without fertilizer, which showed low initial $\mathrm{C}-\mathrm{CO}_{2}$ values that linearly increased during plant development, all OMF treatments showed decreases in the $\mathrm{C}-\mathrm{CO}_{2}$ values during the first ten weeks of cultivation, followed by subsequent increases in $\mathrm{C}-\mathrm{CO}_{2}$ emissions, with the lowest estimated $\mathrm{C}-\mathrm{CO}_{2}$ emission values found at 74,78 , 63 , and 72 DAT for the doses of $50 \%, 100 \%, 150 \%$, and $200 \%$, respectively (Figure $4 B$ ).

When soil basal respiration (SBR) was evaluated in $\mu \mathrm{g} \mathrm{CO}_{2} \mathrm{~g}^{-1}$ soil $h^{-1}$, the same or better results were observed for the OMF treatments at $50 \%$ and $100 \%$ as the mineral fertilizer treatment and, at all DAT apart from 30 DAT, these treatments presented values equal to those observed for the control (Supplementary Table 5).
There were an increases in $\mathrm{C}-\mathrm{CO}_{2}$ emissions per unit biomass $\left(\mathrm{qCO}_{2}\right)$ at 30,60 , and 90 DAT caused by increases in OMF doses, with linear effects at 30 and 90 DAT and quadratic effects at $60 \mathrm{DAT}$, with the highest $\mathrm{qCO}_{2}$ values estimated to occur at a dose of $174.07 \%$ (Table 3 ).

[insert Table 3 here]

When $\mathrm{qCO}_{2}$ was evaluated during plant development, there was a linear increase of the values of the variable due to the increase of the dose in the treatment without fertilizer and an increase of the values until the eleventh week with subsequent decrease of the values for the treatment with organomineral fertilizer at the dose of $50 \%$, with no model fitted for the doses of $100 \%, 150 \%$ and $200 \%$ (Table 3 ).

Evaluation of $\mathrm{qCO}_{2}$ showed that the OMF treatments at doses of $50 \%$ and $100 \%$ lead to values equal to or better than those observed for the mineral fertilizer treatment (Table 3).

\section{Discussion}

The reduced increases in height and diameter at neck height caused by increased doses of OMF in the first 90 DAT (Table 1) may be the result of increased soil salinity due to the use of high doses of fertilizer in a small volume of soil with a high amount of water.

The excessive increase in the concentration of soluble salts in the soil solution can impair water absorption, trigger phytotoxicity processes by specific ions, and may also indirectly interfere with other physiological processes, thus reducing plant growth (Dias et al., 2007).

The increases in $\mathrm{pH}$ to values above 6.0 , observed at 30 DAT in treatments with OMF doses of $150 \%$ and $200 \%$ (Figure $2 \mathrm{~A})$, can be attributed to the alkaline nature of the filter cake used in the fertilizer manufacturing process. The sugar and ethanol manufacturing process involves several broth clarification and colloidal precipitation steps (Almeida Júnior et al., 2011), which are the stages that generate filter cake. In these steps, calcium oxide is added whilst the broth is still hot, causing the residue to have $\mathrm{pH}$ values close to neutral but that may reach up to 8.2 (Meunchang et al., 2005).

The addition of alkaline residues, such as sewage sludge, in eucalyptus forest soils can favor plant growth by reducing soil acidity and by increasing nutrient availability (Guedes et al., 2006).

The initial increases in chlorophyll $a$ and $b$ due to increased nitrogen doses (Table 2) confirm the close relationships among nutrient availability, chlorophyll synthesis, and plant photosynthetic efficiency.

The quadratic behavior of chlorophyll $a$ and $b$ indices as a result of OMF doses indicates a deleterious effect of high doses on the synthesis of these components. High doses of fertilizers may have detrimental effects on seedling development, which is an effect attributed to phytotoxicity and to the inhibition of the absorption of other nutrients (Pias et al., 2013).

The quadratic relationships between fresh and dry mass of the leaves and stems and OMF dose (Figures $1 \mathrm{~A}$ and $1 \mathrm{~B}$ ) allowed us to estimate that the optimal results should be obtained under doses close to $70 \%$ of the recommended dose, indicating the viability of reducing the application dose when using organomineral fertilizers based on filter cake. Studies on sugarcane cultivation (Ramos et al., 2015) and sorghum (Oliveira et al., 2016) have demonstrated the potential of organominerals to substitute and reduce the amount of fertilizer used on crops. Soil salinity, $\mathrm{pH}$ and 
Table 1. Averages of height $(\mathrm{cm})$ and neck height diameter $(\mathrm{cm})$ of Eucalyptus urophylla $\mathrm{x}$ E. grandis plants in Red Latosol under organomineral fertilization based on five levels of sugarcane filter cake $(0 \%, 50 \%, 100 \%, 150 \%$ and $200 \%)$ in relation to the recommended phosphorus $\left(\mathrm{P}_{2} \mathrm{O}_{5}\right)$ level for culture and a mineral fertilizer dose (recommended dose for culture) at 30, 60, 90 and 120 days after transplanting the seedlings.

\begin{tabular}{lllllllll}
\hline \multirow{2}{*}{ Treatments } & \multicolumn{4}{c}{ Height $(\mathrm{cm})^{1}$} & \multicolumn{3}{c}{${\text { Diameter of the lap }(\mathrm{cm})^{1}}^{1}$} \\
\cline { 2 - 9 } & \multicolumn{3}{c}{ Days after transplanting } & \multicolumn{4}{c}{ Days after transplanting } \\
\cline { 2 - 9 } & 30 & 60 & 90 & 120 & 30 & 60 & 90 & 120 \\
\hline Without fertilization & $34.5 \mathrm{a}$ & $48.2 \mathrm{a}$ & $55.8 \mathrm{a}$ & $65.6 \mathrm{a}$ & $0.52 \mathrm{a}$ & $0.60 \mathrm{a}$ & $0.84 \mathrm{a}$ & $0.95 \mathrm{a}$ \\
Mineral fertilizer & $32.8 \mathrm{a}$ & $49.4 \mathrm{a}$ & $57.2 \mathrm{a}$ & $64.8 \mathrm{a}$ & $0.46 \mathrm{a}$ & $0.55 \mathrm{a}$ & $0.72 \mathrm{~b}$ & $0.88 \mathrm{a}$ \\
Organomineral 50\% & $34.3 \mathrm{a}$ & $45.7 \mathrm{a}$ & $56.1 \mathrm{a}$ & $67.5 \mathrm{a}$ & $0.51 \mathrm{a}$ & $0.60 \mathrm{a}$ & $0.75 \mathrm{~b}$ & $0.94 \mathrm{a}$ \\
Organomineral 100\% & $25.4 \mathrm{~b}$ & $34.1 \mathrm{~b}$ & $52.1 \mathrm{a}$ & $65.0 \mathrm{a}$ & $0.32 \mathrm{~b}$ & $0.47 \mathrm{a}$ & $0.69 \mathrm{~b}$ & $0.82 \mathrm{a}$ \\
Organomineral 150\% & $21.6 \mathrm{~b}$ & $28.9 \mathrm{~b}$ & $46.9 \mathrm{a}$ & $58.5 \mathrm{a}$ & $0.27 \mathrm{~b}$ & $0.32 \mathrm{~b}$ & $0.68 \mathrm{~b}$ & $0.84 \mathrm{a}$ \\
Organomineral 200\% & $20.2 \mathrm{~b}$ & $27.2 \mathrm{~b}$ & $29.9 \mathrm{~b}$ & $37.6 \mathrm{~b}$ & $0.25 \mathrm{~b}$ & $0.33 \mathrm{~b}$ & $0.41 \mathrm{c}$ & $0.50 \mathrm{~b}$ \\
\hline
\end{tabular}

${ }^{1}$ Within each variable analyzed, averages followed by distinct letters in the columns differ by the Skott-Konott tests at $5 \%$ probability; ${ }^{2} \mathrm{CV} 1=$ coefficient of variation of the plot; CV2 $=$ subplot coefficient of variation.

A

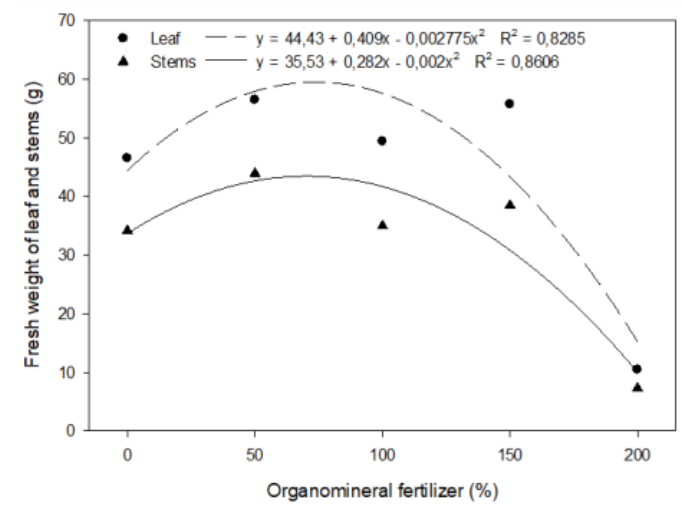

$\mathrm{C}$

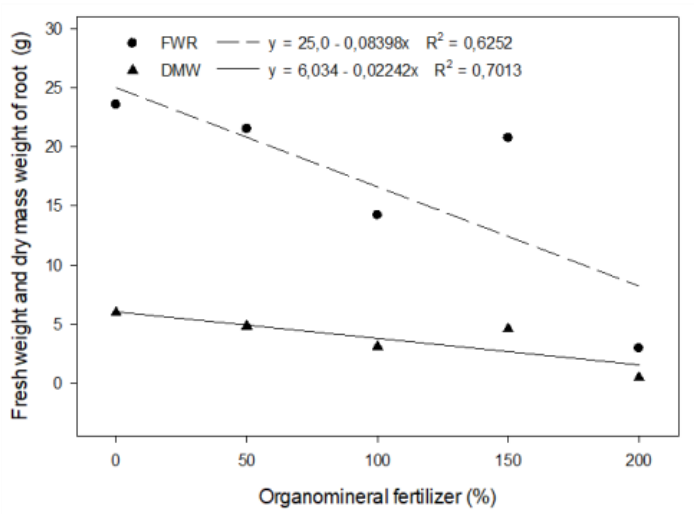

B

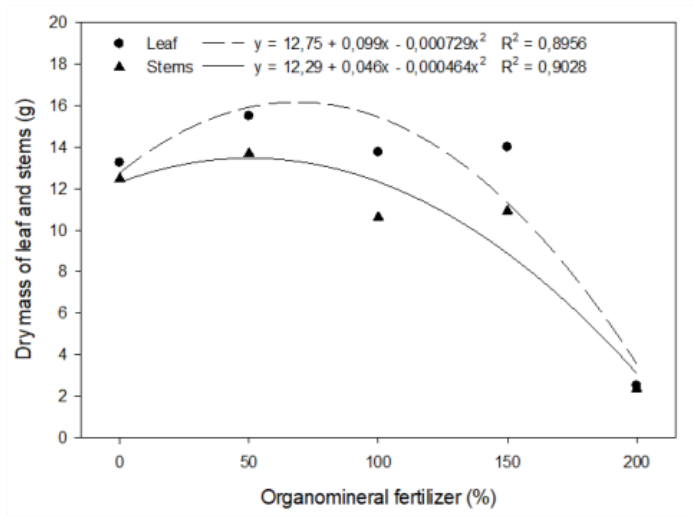

D

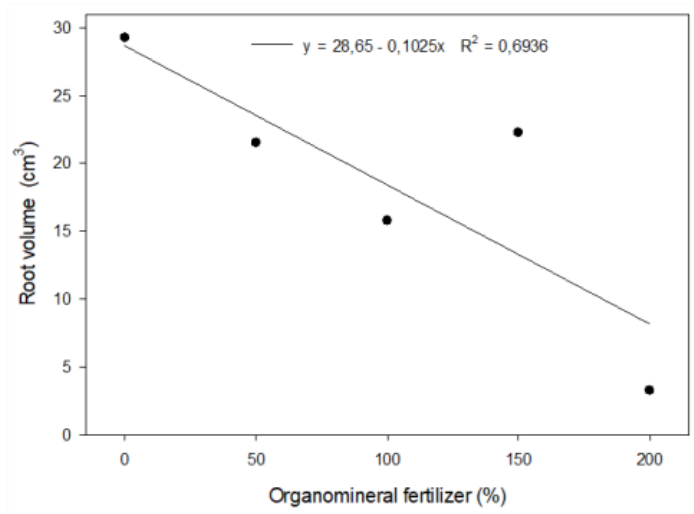

Fig 1. Values of (A) fresh weight of leaves (FWL) and fresh weight of stems (FWS), (B) dry mass leaf (DML) dry mass stem (DMS), (C) fresh mass root ( FWR) and dry mass root (DMW) and (D) root volume (RV) of E. urophylla $\times$ E. grandis plants under organomineral fertilization based on five phosphorus sugarcane filter cake $(0 \%, 50 \%, 100 \%, 150 \%$ and $200 \%)$ compared to that recommended for culture at 120 days after transplantation.

Table 2. Averages of chlorophyll $a\left(C h l \_a\right)$ and chlorophyll $b(C h l b b)$ indices expressed as Falker Chlorophyll Index (FCl) of E. grandis $x$ E. urophylla plants under organomineral fertilization with five phosphorus levels $(0 \%, 50 \%, 100 \%, 150 \%$ and $200 \%)$ in relation to the recommended dose for culture and a dose of mineral fertilizer (recommended dose for culture) at 30, 60, 90 and 120 days after seedling transplantation.

\begin{tabular}{|c|c|c|c|c|c|c|c|c|}
\hline \multirow{3}{*}{ Treatments } & \multicolumn{4}{|c|}{ Chl_a (FCl) ${ }^{1}$} & \multicolumn{4}{|c|}{$C h l \_b(\mathrm{FCl})^{1}$} \\
\hline & \multicolumn{4}{|c|}{ Days after transplanting } & \multicolumn{4}{|c|}{ Days after transplanting } \\
\hline & 30 & 60 & 90 & 120 & 30 & 60 & 90 & 120 \\
\hline Without fertilization & $26.8 \mathrm{~d}$ & $29.5 c$ & $29.2 c$ & $25.3 \mathrm{~b}$ & $6.5 \mathrm{~b}$ & $7.4 \mathrm{c}$ & $7.4 \mathrm{c}$ & $6.1 \mathrm{c}$ \\
\hline Mineral fertilizer & $30.9 c$ & $34.3 \mathrm{~b}$ & $35.1 b$ & $33.9 \mathrm{a}$ & $8.5 \mathrm{a}$ & $10.5 \mathrm{~b}$ & $10.7 \mathrm{~b}$ & $11.6 \mathrm{a}$ \\
\hline Organomineral 50\% & $30.5 c$ & $35.2 \mathrm{a}$ & $37.6 \mathrm{a}$ & $35.3 \mathrm{a}$ & $8.4 \mathrm{a}$ & $11.0 \mathrm{a}$ & $12.4 \mathrm{a}$ & $11.7 \mathrm{a}$ \\
\hline Organomineral $100 \%$ & $31.9 \mathrm{c}$ & $33.9 \mathrm{~b}$ & $35.6 \mathrm{~b}$ & $34.5 \mathrm{a}$ & $9.4 \mathrm{a}$ & $9.9 \mathrm{~b}$ & $10.9 \mathrm{~b}$ & $11.1 \mathrm{a}$ \\
\hline Organomineral 150\% & $35.0 \mathrm{a}$ & $33.1 \mathrm{~b}$ & $36.0 \mathrm{~b}$ & $33.5 \mathrm{a}$ & $11.1 \mathrm{a}$ & $9.5 \mathrm{~b}$ & $11.3 \mathrm{~b}$ & $10.9 \mathrm{a}$ \\
\hline Organomineral 200\% & $33.0 \mathrm{~b}$ & $36.0 \mathrm{a}$ & $37.9 \mathrm{a}$ & $32.2 \mathrm{a}$ & $10.0 \mathrm{a}$ & $11.9 \mathrm{a}$ & $13.7 \mathrm{a}$ & $9.5 \mathrm{~b}$ \\
\hline
\end{tabular}

${ }^{1}$ Within each variable analyzed, averages followed by distinct letters in the columns differ by the Skott-Konott tests at $5 \%$ probability; ${ }^{2} \mathrm{CV} 1=$ coefficient of variation of the plot; $\mathrm{CV} 2=$ subplot coefficient of variation. 
A

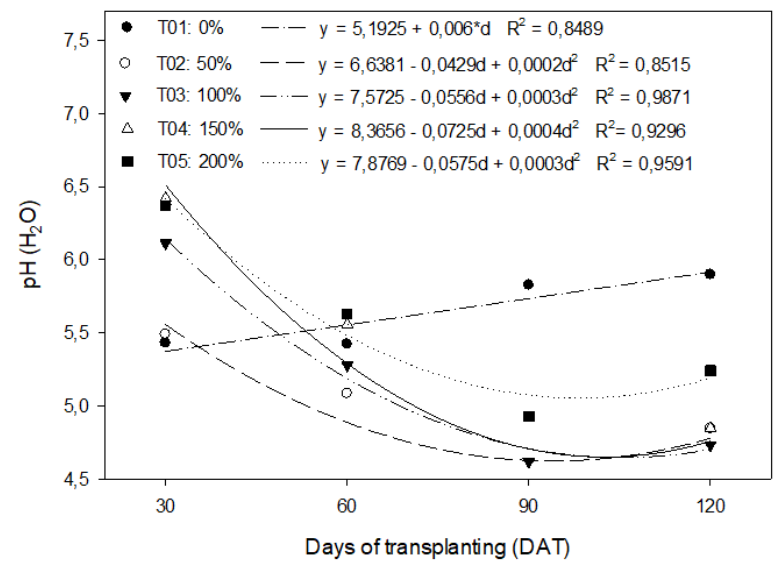

B

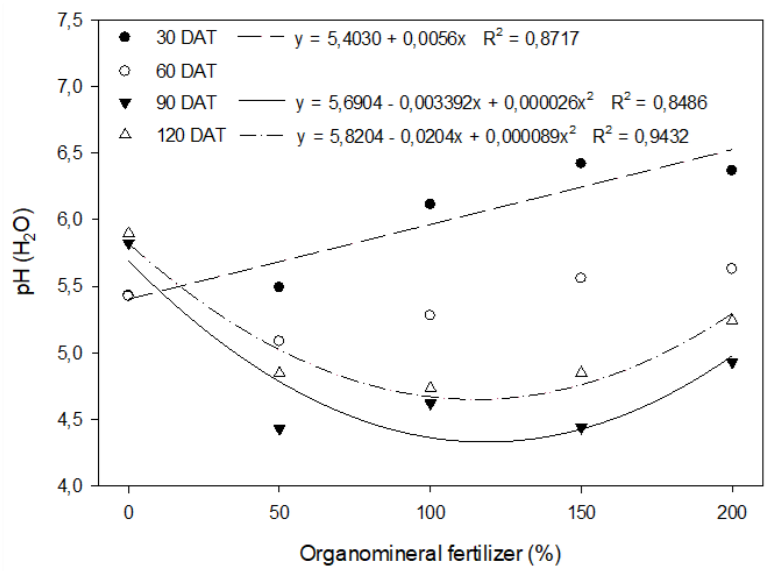

Fig 2. $\mathrm{pH}$ values in $\mathrm{H}_{2} \mathrm{O}(1: 2.5)$ in Red Latosol under cultivation of $E$. urophylla $\times$ E. grandis (A) plants under organomineral fertilization based on five sugarcane filter cake phosphorus levels at 30, 60, 90 and 120 days after transplantation (DAT) and (B) at $30,60,90$ and 120 DAT as a function of organomineral fertilization based on five sugarcane filter cake phosphorus levels $(0 \%, 50 \%$, $100 \%, 150 \%$ and $200 \%$ ) compared to the recommended for the crop

Table 3. Red Latosol metabolic quotient $\left(\mathrm{qCO}_{2}\right)$ under Eucalyptus grandis $\times$ E. urophylla cultivation and under organomineral fertilization with five phosphorus levels $(0 \%, 50 \%, 100 \%, 150 \%$ and $200 \%)$ in relation to the recommended dose and a mineral treatment $(100 \%)$ at $30,60,90$ and 120 days after seedling transplantation.

\begin{tabular}{lllll}
\hline \multirow{2}{*}{ Treatments } & \multicolumn{4}{c}{$\mathrm{qCO}_{2}\left(\mu \mathrm{g} \mathrm{C}-\mathrm{CO}_{2} \mu \mathrm{g}^{-1} \mathrm{MBC} \mathrm{h}^{-1} \times 1000\right)$} \\
\cline { 2 - 5 } & \multicolumn{4}{c}{ Days after transplanting } \\
\cline { 2 - 5 } & 30 & 60 & 90 & 120 \\
\hline Without fertilization & $2.099 \mathrm{a}$ & $2.956 \mathrm{a}$ & $3.396 \mathrm{a}$ & $4.498 \mathrm{a}$ \\
Mineral fertilizer & $4.664 \mathrm{c}$ & $5.415 \mathrm{~b}$ & $6.999 \mathrm{c}$ & $5.097 \mathrm{~b}$ \\
Organomineral 50\% & $3.245 \mathrm{~b}$ & $4.762 \mathrm{~b}$ & $5.556 \mathrm{~b}$ & $4.207 \mathrm{a}$ \\
Organomineral 100\% & $4.754 \mathrm{c}$ & $5.208 \mathrm{~b}$ & $4.337 \mathrm{~b}$ & $6.219 \mathrm{~b}$ \\
Organomineral 150\% & $7.302 \mathrm{~d}$ & $6.104 \mathrm{c}$ & $7.111 \mathrm{c}$ & $5.350 \mathrm{~b}$ \\
Organomineral 200\% & $7.304 \mathrm{~d}$ & $5.897 \mathrm{c}$ & $6.922 \mathrm{c}$ & $5.444 \mathrm{~b}$ \\
\hline & $\mathrm{CV} 1(\%)=12.40$ & \multicolumn{2}{c}{$\mathrm{CV}^{2} 1(\%)=12.40$} \\
\hline
\end{tabular}

${ }^{1}$ Within each variable analyzed, averages followed by distinct letters in the columns differ by the Skott-Konott tests at $5 \%$ probability; ${ }^{2} \mathrm{CV} 1$ = coefficient of variation of the plot; $\mathrm{CV} 2$ = subplot coefficient of variation.

A

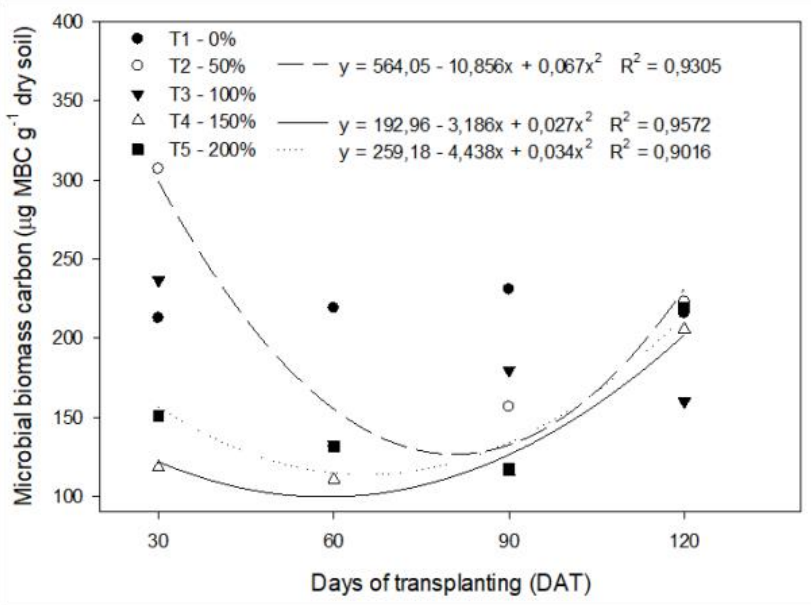

$\mathrm{B}$

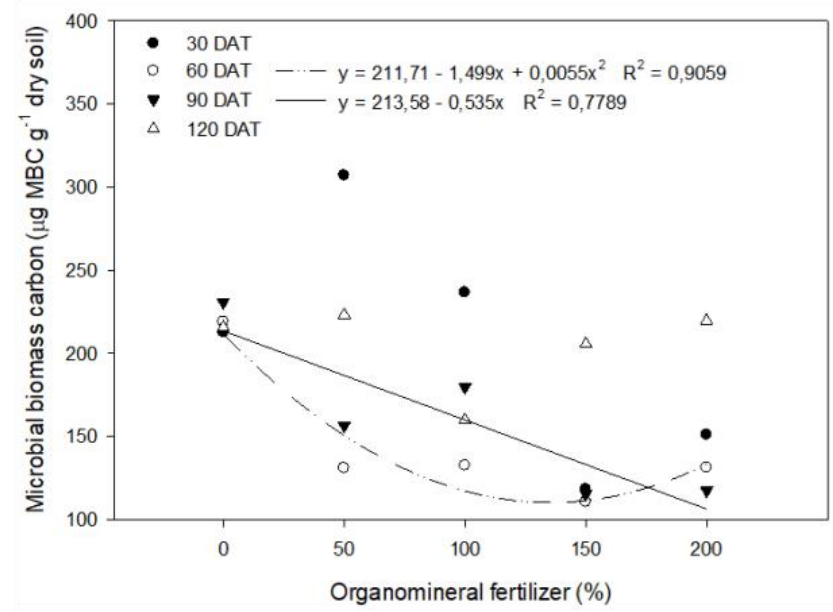

Fig 3. Carbon values of Microbial Biomass in Red Latosol under cultivation of E. urophylla $\times$ E. grandis (A) plants under organomineral fertilization based on sugarcane filter cake with five phosphorus levels at 30,60, 90 and 120 days after transplantation (DAT) and (B) at 30,60, 90 and 120 DAT as a function of organomineral fertilization based on five levels of sugarcane filter cake $(0 \%, 50 \%, 100 \%, 150 \%$ and $200 \%)$ compared to the recommended for the crop. 
Table 4. Treatments specifications and rates and doses of nitrogen, phosphorus pentoxide and potassium oxide in initial cultivation of E. urophylla $\mathrm{x}$ E. grandis (Clone I144).

\begin{tabular}{llll}
\hline \multirow{2}{*}{ Treatments } & $\mathrm{N}$ & $\mathrm{P}_{2} \mathrm{O}_{5}$ & $\mathrm{~K}_{2} \mathrm{O}$ \\
\cline { 2 - 4 } & $\mathrm{g} \mathrm{\text {pot } ^ { - 1 }}$ & & \\
\hline T1: Without fertilization & - & - & - \\
T2: Organomineral fertilizers (50\%) & 2.81 & 11.25 & 3.74 \\
T3: Organomineral fertilizers (100\%) & 5.62 & 22.50 & 7.50 \\
T4: Organomineral fertilizers (150\%) & 8.43 & 33.75 & 11.25 \\
T5: Organomineral fertilizers (200\%) & 11.25 & 45.00 & 15.00 \\
T6: Mineral fertilizer (100\%) & 5.62 & 22.50 & 7.50 \\
\hline
\end{tabular}

- : absence of nutrient. *For the calculation of fertilization levels of $50,100,150$ and $200 \%$ of the $\mathrm{P}_{2} \mathrm{O}_{5}$, the recommendation proposed by the Commission of Soil Fertility of Minas Gerais State (CFSEMG 1999).
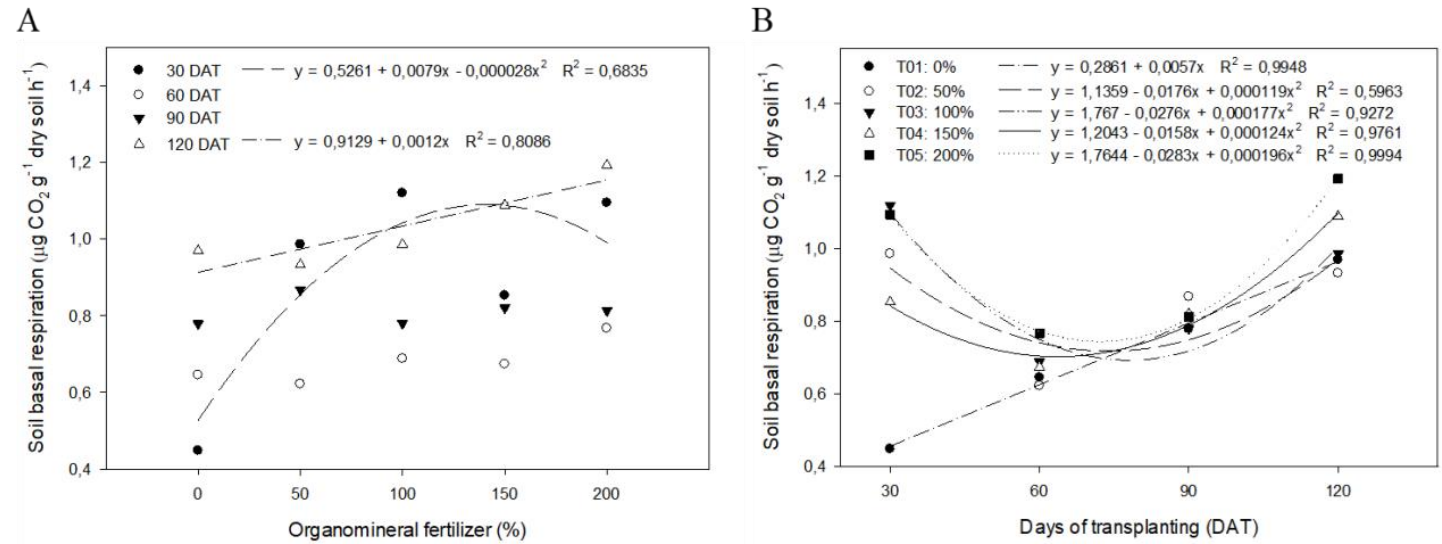

Fig 4. Basal soil respiration (SBR) values in Red Latosol under cultivation of E. urophylla $x$ E. grandis (A) plants at 30, 60, 90 and 120 days after transplantation (DAT) as a function of organomineral fertilization. based on sugarcane filter cake with five phosphorus levels $(0 \%, 50 \%, 100 \%, 150 \%$ and $200 \%)$ in relation to the recommended for the crop and (B) under organomineral fertilization based on sugarcane filter cake with five phosphorus levels at 30, 60, 90 and 120 DAT.

nutritional conditions can determine the structure and activity of soil microbial communities (Zhalnina et al., 2015). Soil microbial biomass and its activity are highly reactive to changes in soil chemical properties, even if these occur on a small scale (Diacono and Montemurro, 2015). Thus, it is proposed that the increase in the doses of organomineral fertilizer and the consequent osmotic stress may have contributed to the reduction of the water potential in the soil solution and, consequently, to the reduction of CBM values. The favoring of the development of bacteria in conditions of high salt concentration and the reduction of fungal growth in these conditions leads to an imbalance of the bacterium / fungus balance, leading to a reduction in the decomposition of recalcitrant carbon sources and consequent to the reduction of microbial biomass. This effect is reported in cotton cultivation (Egamberdieva et al., 2010).

The lowest $M B C$ values were achieved under highest doses of organomineral fertilizer at 30 DAT (Figure 3), which reflects marked increase in soil salinity due to the addition of increasing doses of organomineral fertilizer. The combination of chemical and mineral fertilizers tends to increase soil MBC compared to the addition of strictly mineral fertilizers, a fact attributed to the close relationship between the microbial biomass and the soil organic matter content (Dhull et al., 2004). In millet crops (Kaur, et al., 2005) and apple (Maluche-Baretta et al., 2007), the addition of organic compounds to the soil contributes to the increased microbial biomass of the soil.

The reduction in soil microbial biomass carbon as a result of the application of high doses of nitrogen has been reported in several studies on Eucalyptus genus plants (Wang et al., 2008).
Further, the similar MBC values found among the OMF doses of $50 \%, 150 \%$, and $200 \%$, the control, and the mineral fertilizer treatment 120 DAT show that, despite the initial impact of high OMF doses on microbial biomass, the use of organomineral fertilizers does not negatively affect the development of microbial biomass in the course of seedling development (Figure 3).

The increases in basal soil respiration observed at 30 DAT (Figure 4A) due to increases in OMF coincided with the possible increases in soil salinity due to the increase in the dose of OMF. It was also observed that, similarly to the results observed for $M B C$ (Figure $3 \mathrm{~A}$ ), there was a resumption of the increase in soil basal respiration from the tenth week after transplanting, indicating the beginning of the release of nutrients contained in the pellet (Figure 4B).

The large differences between basal respiration in the fertilization treatments (organomineral and mineral) in relation to the control (Supplementary Table 5) indicate an imbalance in soil microbial activity. The addition of sugarcane filter cake to the soil considerably increases basal respiration (Rasul et al., 2006). In Brazilian sugarcane cultivation, the addition of residues from the manufacturing process to the soil, such as vinasse, instead of mineral fertilization significantly increases $\mathrm{C}-\mathrm{CO}_{2}$ emissions (Carmo et al., 2013).

However, it was observed that the addition of OMF at doses correlating to $50 \%$ and $100 \%$ of the reference dose showed basal soil respiration values equal to or better than those under the mineral fertilizer treatment at the reference dose. This allows us to make inferences regarding the sustainability of the product in comparison to strictly mineral fertilization.

The increases in the metabolic quotient caused by the 
increased doses of organomineral fertilizer at 30, 60, and 90 DAT (Table 3 ) indicate a reduction in the efficiency of carbon assimilation by the biomass. However, for the OMF doses of $50 \%$ and $100 \%$, the metabolic quotients were equal to or lower than those observed under the mineral fertilizer treatment at the reference dose. The organomineral treatment at $50 \%$ produced a mean metabolic quotient that was equal to that observed in the control (Table 3), indicating that the replacement of mineral fertilization with organomineral fertilization may be viable for $E$. urophylla $\times E$. grandis implantation.

The addition of organic compounds to the soil, especially to the superficial layers, can increase the amount of organic carbon in these layers. Organic carbon is the basis for soil microbial processes, and thus increasing the amount of organic carbon increases the activity of these communities (Maluche-Baretta et al., 2007).

\section{Materials and methods}

\section{Plant materials}

In this study, the interspecific hybrid interspecific hybrids such as E. urophylla $\times$ E. grandis (Clone 1144) were used due to the greater plasticity in adapting to different environments, the fast and good growth of $E$. grandis and high density of wood, rusticity and resistance to $E$. urophylla water deficit (Fowler, 2014).

\section{Implantation and trial process with plants}

The experiment was carried out in a greenhouse located in the municipality of Ituiutaba-MG (18058'18.98" South and 49-26'54.128" West) at an altitude of $573 \mathrm{~m}$, from the $5^{\text {th }}$ of March of 2018 to the $3^{\text {rd }}$ of July of 2018 . The climate of the region is Awh tropical, defined by hot and rainy summers and dry winters. During the study, the average temperature inside the greenhouse was $25^{\circ} \mathrm{C}$ (maximum: $36.3^{\circ} \mathrm{C}$, minimum: $\left.10.6^{\circ} \mathrm{C}\right)$, and average humidity was $59 \%$ (maximum: $86 \%$, minimum: 21\%) (Supplementary - Figure 1). The experimental design was a randomized block design in a split plot in time with four replications per treatment. The plots were evaluated the effects of different doses of fertilizer $(0 \%, 50 \%, 100 \%, 150 \%$ e $200 \%)$ in relation to the recommended fertilizer dose for the crop and plot the effect of time (30,60, 90 and 120 days after transplanting - DAT).

The recommended doses of fertilizers (Table 4) were defined based on the recommended $\mathrm{P}_{2} \mathrm{O}_{5}$ content to be applied to soil (Soil Fertility Commission of the State of Minas Gerais [CFSEMG], 1999).

[insert Table 4 here]

The organomineral fertilizer $06-24-08+8 \%$ of Total Organic Carbon (TOC) containing sugarcane filter cake, urea, monoammonium phosphate, and potassium chloride (Supplementary Table 6) was administered. The mineral fertilizer treatment was derived from the same sources as the organomineral fertilizer. Fertilization with micronutrients was performed via irrigation.

The soil used as substrate was Red Latosol with the following initial properties: $\mathrm{pH}_{\mathrm{H} 2 \mathrm{O}}-5.1, \mathrm{pH}_{\mathrm{CaCl}_{2}}-4.5, \mathrm{P}_{\mathrm{meh}}-2.2 \mathrm{mg} \mathrm{dm}^{-}$ ${ }^{3}, \mathrm{P}$-resin $-3.0 \mathrm{mg} \mathrm{dm}^{-3}, \mathrm{~K}^{+}-34 \mathrm{mg} \mathrm{dm}^{-3}, \mathrm{~S}^{-\mathrm{SO}_{4}{ }^{2-}-5.0 \mathrm{mg}}$ $\mathrm{dm}^{-3}, \mathrm{Ca}^{2+}-0.8 \mathrm{cmol}_{\mathrm{c}} \mathrm{dm}^{-3}, \mathrm{Mg}^{2+}-0.2 \mathrm{cmol}_{\mathrm{c}} \mathrm{dm}^{-3}, \mathrm{Al}^{3+}-0.6$ $\mathrm{cmol}_{\mathrm{c}} \mathrm{dm}^{-3}, \mathrm{H}+\mathrm{Al}-3.0 \mathrm{cmol}_{\mathrm{c}} \mathrm{dm}^{-3}$, M.O. $-1.0 \mathrm{dag} \mathrm{kg}^{-1}$, C.O. $0.55 \mathrm{dag} \mathrm{kg}^{-1}, \mathrm{~B}-0.17 \mathrm{mg} \mathrm{dm} \mathrm{m}^{-3}, \mathrm{Cu}-0.4 \mathrm{mg} \mathrm{dm} \mathrm{m}^{-3}, \mathrm{Fe}-28 \mathrm{mg}$ $\mathrm{dm}^{-3}, \mathrm{Mn}-1.6 \mathrm{mg} \mathrm{dm} \mathrm{m}^{-3}, \mathrm{Zn}-0.8 \mathrm{mg} \mathrm{dm}{ }^{-3}$, total sand $-650 \mathrm{~g}$ $\mathrm{kg}^{-1}$, silt $-75 \mathrm{~g} \mathrm{~kg}^{-1}$, and clay $-275 \mathrm{~g} \mathrm{~kg}^{-1}$.
After being collected from the $0-20 \mathrm{~cm}$ layer of a seven-yearold eucalyptus production area in the municipality of Ituiutaba, MG, Brazil, the soil was passed through a $5.64 \mathrm{~mm}$ sieve and was corrected with dolomitic limestone $0.31 \mathrm{~g}$ $\mathrm{dm}^{3}$ ), in accordance with the requirements of the cultivation. The soil was then incubated under a humidity level corresponding to $70 \%$ of the field capacity for 30 days in plastic bags. At the end of this period, the $\mathrm{H}_{2} \mathrm{O}$ and $\mathrm{CaCl}_{2}$ $\mathrm{pH}$ values were 5.2 and 5.15 , respectively.

The substrate was placed in pots with 11-liter capacity, into which $2.0 \mathrm{~kg}$ of crushed stone $(6.4 \mathrm{~mm})$, a geotextile blanket, and $10 \mathrm{~kg}$ of dry soil were sequentially placed. After the contents was manually compacted, the pots presented density values of between 1.7 and $1.8 \mathrm{~g} \mathrm{~cm}^{-3}$, and the water retention capacities (WRC) of the pots were estimated using the direct gravimetric method.

The fertilizer was applied and homogenized manually, and the water content of the pots was adjusted to $70 \%$ of the water retention capacity (WRC). Healthy, 30-day-old Eucalyptus urophylla x Eucalyptus grandis hybrid (Clone 1144) seedlings, which were uniform in stem diameter, were transplanted into the experimental plots. The plants were irrigated daily to maintain a water content close to $70 \%$ of the WRC.

\section{Evaluation of plant morphophysiological characteristics}

Diameter at neck height $(\mathrm{mm})$ and plant height $(\mathrm{cm})$ were determined at 30,60,90, and 120 DAT, by measuring the distance between the neck and the insertion of the last pair of fully open leaves.

Chlorophyll $a$ and $b$ contents were determined at 30, 60, 90, and 120 DAT using an indirect method involving a chlorophyll meter (ClorofiLog CFL 1030 Falker Agricultural Automation, 2008) according to the manufacturer's instructions.

At 120 DAT, plants were collected and separated into shoot (leaves, stem, and branches) and root systems, with the fresh mass of the leaves (FML), fresh mass of the stem and branches (FMS), and fresh mass of the roots (FMR) being evaluated. To evaluate leaf area, all leaves from the plants of each experimental unit were collected. The leaves were weighed, packed in plastic bags, and transported in boxes with ice to the laboratory, where leaf area was determined in an integrator $\mathrm{LI}^{-\mathrm{COR}^{\circ}}$, model $\mathrm{LI} 3100$.

The volume of the roots $\left(\mathrm{cm}^{3}\right)$ was determined in a graduated beaker $(500 \mathrm{~mL})$, where the roots, after washing, were immersed in a known water volume, with the volume of the root being determined by the displacement of the water column.

To determine the dry mass of the leaves (g) (DML), dry mass of the stem (g) (DMS), and dry mass of the roots (g) (DMR), the material, after being packed in paper bags, was submitted to drying in a forced circulation oven at $65^{\circ} \mathrm{C}$ until a constant weight was achieved.

\section{Sampling and chemical analysis of the soil}

Soil samples were collected at 30,60,90, and 120 DAT. The samples (three in each pot of the plot) were collected in the 0-15 cm soil layer, and were immediately transferred to sealed flasks and transported in a box with ice to the laboratory. After sieving $(<2.0 \mathrm{~mm})$, they were their moisture contents were determined. The samples were kept at $4^{\circ} \mathrm{C}$ for up to one week prior to the analyses.

The $\mathrm{pH}$ of the soil was evaluated in an aqueous suspension at a ratio of 1:2.5 (Teixeira et al., 2017). The TOC was 
determined at 120 DAT using the wet oxidation method (Walkley \& Black, 1934).

\section{Microbiological soil analyses}

Microbial biomass carbon (MBC) was estimated using the fumigation extraction method (Vance et al., 1987). The carbon content was determined using the colorimetric method (Bartlett \& Ross, 1988) using a Kc value of 0.33 (Kaschuk et al., 2010).

Soil basal respiration (SBR) was determined by incubating 50 $\mathrm{g}$ of soil under a humidity level corresponding to $60 \%$ of the field capacity, in a hermetically sealed glass bottle $(500 \mathrm{~mL})$ containing $10 \mathrm{~mL}$ of $0.5 \mathrm{M} \mathrm{NaOH}$. Evolved $\mathrm{CO}_{2}$ determination was performed every seven days for 28 days by indirect titration of the residual $\mathrm{NaOH}$ with standardized $\mathrm{HCl}$ (Anderson, 1982).

Metabolic quotient $\left(\mathrm{qCO}_{2}\right)$ values were calculated from the $\mathrm{MBC}$ and $\mathrm{RB}$ values, and represent the $\mathrm{C}-\mathrm{CO}_{2}$ release rate per unit of carbon of the microbial biomass per unit of time (Anderson \& Domsch, 1985).

\section{Data analysis}

The data were checked for assumptions of normality using Kolmogorov-Smirnov tests (KS), and for homogeneity of variances using Levene's test, using the SPSS 11.5 software package. Analyses of variance were performed for all analyzed variables, and, when the differences were significant, the smallest significant difference $(P<0.05)$ was used to separate the variables in the Sisvar software Version 5.6. Graphics were produced using the Systat 11.0 software.

\section{Conclusion}

Organomineral pelletized fertilizers based on sugarcane filter cake enable the reduction of soil acidity and do not harm the activity of carbon and microbial biomass of the cultivated soil of $E$. urophylla $\times$ E. grandis, presenting themselves as possible substitutes for mineral fertilization for the implementation of eucalyptus forests.

\section{Acknowledgements}

The authors gratefully acknowledge Geociclo Biotecnologia S/A for operational support.

\section{References}

Almeida Júnior $A B$, Nascimento $C W$, Sobral MF, Silva FB, Gomes WA (2011) Soil fertility and uptake of nutrients by sugarcane fertilized with filter cake. Revista Brasileira de Engenharia Agrícola e Ambiental. 15: 1004-1014.

Anderson JP (1982) Soil respiration. Methods of Soil Analysis: Part 2 Chemical and Microbiological Properties. 9: 831871.

Anderson TH, Domsch KH (1985) Determination of ecophysiological maintenance carbon requirements of soil microorganisms in a dormant state. Biol Fertil Soils. 1(2): 81-89.

Araújo A, Monteiro R (2007) Indicadores biológicos de qualidade do solo. Bioscience Journal. 23:66-75.

Barros NF, Comerford NB (2002) Sustentabilidade da produção de florestas plantadas na região tropical. In: Alverez VVH, Schaefer CEGR, Barros NF, Mello JWV, Costa LM (Eds.). Tópicos em ciência do solo. Viçosa, MG: Sociedade Brasileira de Ciência do Solo. 2: 487-592.
Bartlett R, Ross D (1988) Colorimetric Determination of Oxidizable Carbon in Acid Soil Solutions. Soil Sci Soc Am J. 52:1191.

Bünemann E, Bongiorno G, Bai Z et al. (2018) Soil quality - A critical review. Soil Biol Biochem. 120:105-125.

Carmo JBD, Filoso S, Zotelli LC, Sousa Neto ER, Pitombo LM, Duarte-Neto PJ, Cantarella H (2012) Infield greenhouse gas emissions from sugarcane soils in Brazil: effects from synthetic and organic fertilizer application and crop trash accumulation. Glob Change Biol Bioenergy. 5:267-280.

Comissão de Fertilidade do Solo do Estado de Minas Gerais [CFSEMG]. (1999) Recomendações para o uso de corretivos e fertilizantes em Minas Gerais: 5a aproximação.

Companhia Nacional de Abastecimento - CONAB. Acompanhamento da Safra Brasileira: Cana-de-açúcar. Safra2018/2019 (Online) Available at: [Accessed: 22 Jun. 2020].

Cruz A, Pereira F, Figueredo V (2017) Fertilizantes organominerais de resíduos do agronegócio: avaliação do potencial econômico brasileiro. In: BNDES Setorial 45. Rio de Janeiro, Banco Nacional de Desenvolvimento Econômico e Social. 2017: 137-187

Diacono M, Montemurro F (2015) Effectiveness of organic wastes as fertilizers and amendments in salt-affected soils. Agriculture. 5(2): 221-230.

Dias NS, Duarte SN, Teles Filho JF, Yoshinaga RT (2007) Salinização do solo por aplicação de fertilizantes em ambiente protegido. Irriga. 12(1): 135-143.

Dhull S, Goyal S, Kapoor K, Mundra M (2004) Microbial biomass carbon and microbial activities of soils receiving chemical fertilizers and organic amendments. Arch Agron Soil Sci. 50:641-647.

Egamberdieva D, Renella G, Wirth S, Islam R (2010) Secondary salinity effects on soil microbial biomass. Biol Fertil Soils. 46(5): 445-449.

Fowler J (2014) Produção, armazenamento e comercialização de sementes de eucalipto no Brasil. In: Vale A, Machado C, Pires J et al. (ed) Eucaliptocultura no Brasil, silvicultura, manejo e ambiência. SIF, Viçosa, Minas Gerais, Brazil, pp 87-102

Guedes M, Andrade C, Poggiani F, Mattiazzo M (2006) Propriedades químicas do solo e nutrição do eucalipto em função da aplicação de lodo de esgoto. Rev Bras Cienc Solo. 30:267-280.

IBÁ (2018) Sumário Executivo da Indústria Brasileira de Árvores: ano base 2017. IBÁ, Brasília. https://www.iba.org/datafiles/publicacoes/relatorios/digit al-sumarioexecutivo-2018.pdf. Accessed 26 September 2018

Kaschuk G, Alberton O, Hungria M (2010) Three decades of soil microbial biomass studies in Brazilian ecosystems: Lessons learned about soil quality and indications for improving sustainability. Soil Biol Biochem. 42:1-13.

Kaur K, Kapoor K, Gupta A (2005) Impact of organic manures with and without mineral fertilizers on soil chemical and biological properties under tropical conditions. J Soil Sci Plant Nutr. 168:117-122.

Maluche-Baretta C, Klauberg-Filho O, Amarante C, Ribeiro G, Almeida D (2007) Atributos microbianos e químicos do solo em sistemas de produção convencional e orgânico de maçãs no estado de Santa Catarina. Rev Bras Cienc Solo. 31(4): 655-665.

Meunchang S, Panichsakpatana S, Weaver R (2005) Cocomposting of filter cake and bagasse; by-products from a sugar mill. Bioresour Technol. 96:437-442. 
Oliveira DP, de Camargo R, Lemes EM, Lana RMQ, Matos ALIA, Magela MLM (2017) Organic matter sources in the composition of pelletized organomineral fertilizers used in sorghum crops. Afr J Agric Res. 12, 2574-2581.

Pias OHC, Cantarelli EB, Berghetti J, Leschewitz R, Kluge ER, Somavilla L (2013) Doses de fertilizante de liberação controlada no índice de clorofila e na produção de mudas de grápia. Pesqui Florest Bras. 33:19-25.

Ramos LA, Lana RMQ, Korndorfer GH, Silva AS (2015) Effect of organo-mineral fertilizer and poultry litter waste on sugarcane yield and some plant and soil chemical properties. Afr J Agric Res. 12, 20-27.

Rasul G, Appuhn A, Müller T, Joergensen R (2006) Salinityinduced changes in the microbial use of sugarcane filter cake added to soil. Appl Soil Ecol. 31:1-10.

Ribeiro H, Vasconcelos E, Ramos A, Coutinho J (2009) Avaliação do estado nutricional azotado de pés-mãe de Eucalyptus globulus Labill. ssp. globulus com recurso a um medidor portátil de clorofila. Revista de Ciências Agrárias. 32:40-49.

Romano E, Brambilla M, Bisaglia C, Pampuro N, Pedretti EF, Cavallo E (2014) Pelletization of composted swine manure solid fraction with different organic co-formulates: effect of pellet physical properties on rotating spreader distribution patterns. Int J Recycl Org Waste Agricult. 3:101-111.

Teixeira PC, Donagemma GK, Fontana A, Teixeira WG (2017) Manual de Métodos de Análise de Solo. Embrapa SolosLivro técnico (INFOTECA-E).

Vance E, Brookes P, Jenkinson D (1987) An extraction method for measuring soil microbial biomass $C$. Soil Biol Biochem. 19:703-707.

Walkley A, Black I (1934) An examination of the degtjareff method for determining soil organic matter, and a proposed modification of the chromic acid titration method. Soil Science. 37:29-38.

Wang Q, Wang S, Liu Y (2008) Responses to N and P fertilization in a young Eucalyptus dunnii plantation: Microbial properties, enzyme activities and dissolved organic matter. Appl Soil Ecol. 40:484-490.

Zhalnina K, Dias R, Quadros PD, Davis-Richardson A, Camargo FA, Clark IM, Triplett EW (2014) Soil pH Determines Microbial Diversity and Composition in the Park Grass Experiment. Microb Ecol. 69:395-406.

Zhao J, Wan S, Fu S et al. (2013) Effects of understory removal and nitrogen fertilization on soil microbial communities in Eucalyptus plantations. For Ecol Manage. 310:80-86. 